\title{
Human Immunodeficiency Virus Type 1 (HIV-1) Reverse Transcriptase Inhibitory Effect of Cymbopogon Nardus Essential Oil
}

\author{
Kazuya Mori $^{1 *}$, Etienne Kochole Obossou ${ }^{1}$, Shoutaro Suwa ${ }^{1}$, Shougo Miura ${ }^{1}$, \\ Soon $\mathrm{Oh}^{1}$, Natsuki Jinbo ${ }^{1}$, Yukiko Ishibashi ${ }^{1}$, Yasuo Shikamoto ${ }^{1}$, Tetsuji Hosono ${ }^{2}$, \\ Takahiro Toda $^{3}$, Koji Tomobe ${ }^{3}$, Tatsuo Shinozuka ${ }^{3}$, Shigeo Nakajo ${ }^{1}$ \\ ${ }^{1}$ Department of Biochemistry, Yokohama University of Pharmacy, Yokohama, Japan \\ ${ }^{2}$ Department of Medicinal Microbiology, Yokohama University of Pharmacy, Yokohama, Japan \\ ${ }^{3}$ Department of Pathophysiology, Yokohama University of Pharmacy, Yokohama, Japan \\ *k.mori@hamayaku.ac.jp
}

\begin{abstract}
The essential oil (EO) obtained from Cymbopogon nardus is used frequently as ingredients of antiAIDS medication in Africa by indigenous people who rely mainly on traditional medicinal plant therapies. However, its mechanism still remains obscure. The present study investigated the biological effects of the EO derived from $C$. nardus collected in Benin on the activities of human immunodeficiency virus reverse transcriptase (HIV-1 RT) and Escherichia coli DNA polymerase I (DNA-POL I). Biochemical experiments showed that C. nardus EO inhibited the activity of HIV-1 RT, whereas it had no effect on DNA-POL I. To investigate the specificity of these biological effects of $C$. nardus, six other representatives EOs were assayed in the same way in order to determine their effects on HIV-1 RT and DNA-POL I. None of the other six EOs had significant effect on the activities of these two enzymes. Gas chromatography-mass spectrometry analysis of the $E O$ obtained from the aerial parts of $C$. nardus by steam distillation identified among other constituents: (S)- $\beta$ citronellol, $(R)$-linalool, $(R)$-limonene, geraniol and $(R)$-citronellal. In particular, $(S)$ - $\beta$-citronellol inhibited $H I V-1$ RT in vitro biochemical assay where the same concentration as $C$. nardus $E O$ was used in the experiment.
\end{abstract}

Keywords: (S)-B-citronellol, Cymbopogon nardus, Poaceae, DNA polymerase I, Escherichia coli, essential oil, HIV-1 reverse transcriptase.

\section{INTRODUCTION}

Early in 1981, acquired immunodeficiency syndrome (AIDS) emerged suddenly among homosexuals and injected drug users in the United States (Gottlieb et al. 2006, Sharp et al. 2011). Subsequently, AIDS spread rapidly to become a global public health pandemic. Montagnier et al. isolated human immunodeficiency virus (HIV) from the blood of an AIDS patient in 1983 and identified it as the etiological agent of this devastating disease. Thus, many HIV-1 enzymes and proteins have been targeted in anti-HIV drug research (Barré-Sinoussi et al. 1983, Sepkowitz et al. 2001, Bär et al. 2004, Bauman et al. 2008, Sarafinos et al. 2009). Many antiretroviral drugs have been designed and classified according to their targets, including reverse transcriptase (RT) inhibitors, integrase inhibitors, protease inhibitors, and entry inhibitors (De Clercq 2009, Sayana et al. 2009, Chen et al. 2013, Dijk et al. 2013, Yu et al. 2013).

The standard cocktail therapy (highly active antiretroviral therapy, HAART) used recently in developed countries is very effective in suppressing viral replication and it has significantly reduced the mortality rate of HIV/AIDS patients, as well as improving their quality of life (Antonella et al. 2000, Chou et al. 2005). However, HAART has only reached a fraction of people in Sub-Saharan Africa where up to two-thirds of the world's total HIV/AIDS patients experience many treatment 
problems (Cohen et al. 2008, World Health Organization 2011, World Health Organization 2012). These problems include a major lack of adequate therapy due to the high costs of anti-AIDS drugs, the unavailability of anti-AIDS drugs and various complex side effects, such as the emergence of antiAIDS drug resistance (Hawkins 2006, Rosen et al. 2007, Park et al. 2009, History of HIV and AIDS in Africa 2013, Ziske et al. 2013). In this problematic background, african communities have developed many effective natural medicines from traditional therapeutic plants (Leteane et al. 2012). Cymbopogon nardus (C. nardus) is a perennial grass in the Poaceae family, which grows in tropical areas such as Sri Lanka, Africa, and Java and it is one of the most frequently used plants in traditional anti-AIDS drug preparations. The essential oil (EO) obtained from the leaves and stems of C. nardus by steam distillation has also been used to treat infections in the past in Africa (Wei et al. 2013). However, the mechanism that underlies its therapeutic efficacy still remains obscure.

In the present study, an in vitro biochemical investigation showed that the EO derived from C. nardus inhibited HIV-1 RT activity in a dose-dependent manner. Gas chromatography-mass spectrometry (GC-MS) analysis of this EO sample identified several constituents and their activities were assayed against HIV-1 RT and Escherichia coli DNA polymerase I (DNA-POL I). The results showed that $(S)-\beta$-citronellol might be one of the constituents of $C$. nardus with inhibitory effects on HIV-1 RT.

\section{Materials AND MethodS}

\subsection{Reagents}

C. nardus EO, Ocimum gratissimum EO, Lippia multiflora EO, C. citratus EO, Melaleuca viridiflora leaf EO and Eucalyptus obliqua leaf EO were all steam distilled extracts from these plants, which were purchased from Aronat + (Benin). Commercial $(R)$-citronellal (purity $>90 \%$ by GC), $(R)$-linalool (purity $>98 \%$ by GC), geraniol (purity $>97 \%$ by GC) and $(R$ )-limonene (purity $>95 \%$ by GC) were purchased from Wako. $(S)$ - $\beta$-citronellol (purity $>95 \%$ by GC) was purchased from Tokyo Chemical Industry Co. Ltd. ddTTP (purity 99\% by HPLC) was purchased from Amsterdam Biosciences inhibition assay. Neomycin trisulfate salt hydrate (potency $>600 \mu \mathrm{g}$ per $\mathrm{mg}$ ) was purchased from Sigma-Aldrich. The RT assay colorimetric kit, biotin-16-dUTP, digoxigenin deoxyuridine triphosphate (DIG-dUTP), DNA-dependent DNA-POL I from Escherichia coli lysogenic NM 964, deoxynucleoside triphosphate set (PCR grade) and hexanucleotide mix $(10 \times$ concentration) were purchased from Roche. Single-stranded DNA from calf thymus (purity $>65 \%$ ) was purchased from Sigma-Aldrich.

\subsection{Evaluation of HIV-1 RT Inhibitory Effect}

The quantitative determination of the HIV-1 RT inhibitory effect of EO used a colorimetric enzyme immunoassay, which involved the incorporation of DIG-and biotin-labeled dUTP into native DNA. The assay was performed with an RT assay colorimetric kit, according to the manufacturer's instructions with slight modifications. Briefly, $60 \mu \mathrm{L}$ of a reaction mixture containing final concentrations of $46 \mathrm{mM}$ Tris- $\mathrm{HCl}, 266 \mathrm{mM} \mathrm{KCl}, 27.5 \mathrm{mM} \mathrm{MgCl}_{2}, 9.2 \mathrm{mM}$ dithiothreitol (DTT), 10 $\mu \mathrm{M}$ biotin-16-dUTP/DIG-dUTP, $2.2 \mu \mathrm{g} / \mathrm{mL}$ PolyA:oligo (dT) 15 template/primer hybrid, $1.7 \mathrm{ng} / \mathrm{mL}$ HIV-1 RT and various concentrations of sample $(0.1-10 \mathrm{mg} / \mathrm{mL})$ was incubated at $37^{\circ} \mathrm{C}$ for $15 \mathrm{~h}$. The reaction mixture was transferred to the surface of streptavidin-coated ELISA plate wells. After washing away any unbound substances, an antibody directed against DIG conjugated to peroxidase (anti-DIG-POD) was added that bound to DIG-11-dTTP. After one more wash, 2,2-azinobis (3ethylbenzothiazoline-6-sulphonic acid) diammonium salt (ABTS) was added. The absorbance $\left(\mathrm{OD}_{405 \mathrm{~nm}}\right)$ of the color that developed in the presence of ABTS was evaluated at $405 \mathrm{~nm}$ using an Enzyme-Linked Immunosorbent Assay (ELISA) microplate reader (SpectraMax 340PC). A reaction solution where the inhibitor was replaced with dilution buffer was used as the control. A sample without RT solution was used as the negative control and a sample with $2 \mu \mathrm{M}$ ddTTP was used as the positive control. EOs were dissolved in ethanol to prepare a dilution series that ranged from 0.1 $\mathrm{mg} / \mathrm{mL}$ to $10 \mathrm{mg} / \mathrm{mL}$. The final ethanol concentration in the solutions was $<1 \%$, which had no effect on the assay results. The inhibitory effects of RT inhibitors were calculated as the percentage inhibition relative to the control, as follows:

Control relative percentage of inhibition $=100-\left[\left(\right.\right.$ Sample $\mathrm{OD}_{405 \mathrm{~nm}}-$ Negative control $\left.\mathrm{OD}_{405 \mathrm{~nm}}\right) /$

$\left(\right.$ Control OD $405 \mathrm{~nm}-$ Negative control $\left.\left.\mathrm{OD}_{405 \mathrm{~nm}}\right)\right] \times 100$. 


\subsection{Evaluation of DNA-POL I Activity}

Evaluations of the effects of EOs on the activity of DNA-POL I were performed as described by Ducancelle et al., with slight modifications (Ducancelle et al. 2007). The DNA-POL I activity was assayed by measuring the incorporation of DIG-dUTP into the complementary DNA chain. Calf thymus DNA was used as the template with a mixture of hexanucleotides designed as random primers. Briefly, $20 \mu \mathrm{L}$ of a reaction mixture containing final concentrations of $50 \mu \mathrm{g} / \mathrm{mL}$ calf thymus DNA, $50 \mathrm{mM}$ Tris- $\mathrm{HCl}$ (pH7.2), $10 \mathrm{mM} \mathrm{MgCl} 2,0.1 \mathrm{mM}$ DTT, $0.2 \mathrm{mg} / \mathrm{mL}$ Bovine serum albumin (BSA), dATP, dGTP, dCTP, dTTP, DIG-dUTP, biotin-16-dUTP and various concentrations of inhibitor $(0.1-10 \mathrm{mg} / \mathrm{mL})$ was incubated at $37^{\circ} \mathrm{C}$ for $15 \mathrm{~h}$. The subsequent steps were performed in the same manner as the "Evaluation of HIV-1 RT inhibitory effect" described above. A sample without DNA-POL I solution was used as the negative control and a sample with $10 \mathrm{mM}$ Neomycin trisulfate salt hydrate was used as the positive control. The ethanol concentration in the reaction mixtures was $<1 \%$, which had no effect on the activity of DNA-POL I.

\subsection{Identification of the Major Constituents of $\boldsymbol{C}$. Nardus EO}

C. nardus EO was analyzed by GC-MS, as described by Kudo et al. (2009), using an Agilent 6890 GC combined with an Agilent 5973 MS. NAGINATA software was provided by Nishikawa. A HP$5 \mathrm{~ms}$ fused silica capillary column ( $30 \mathrm{~m}$ x $0.25 \mathrm{~mm}$ i.d., $0.25 \mu \mathrm{m}$ film thickness, Agilent) coated with $5 \%$ phenylmethyl-silicone stationary phase was used. The GC-MS data analysis was performed using NIGINATA software based on the "free-drug database" and the "drug database with acetylating reagents".

\subsection{Statistical Analysis}

The results were analyzed using the Student's $t$-test. Differences were considered significant at $p<$ 0.05

\section{RESULTS}

Efficacy and toxicity are two indispensable parts of EO activity evaluation, so the biological effects of C. nardus EO on HIV-1 RT were examined to assess its efficacy, whereas its effects on DNA-POL I were assessed to determine its toxicity. $C$. nardus $\mathrm{EO}$ had a dose-dependent inhibitory effect $\left(\mathrm{IC}_{50}\right.$ value of $1.2 \mathrm{mg} / \mathrm{mL}$ ) against HIV-1 RT at concentrations ranged from 0.1 to $10 \mathrm{mg} / \mathrm{mL}$ (Fig. 1A). With $\leq 10 \mathrm{mg} / \mathrm{mL}$ of $C$. nardus EO, the activity of HIV-1 RT was significantly inhibited by up to $72.4 \%$ compared with the control $(p<0.001)$. This inhibitory effect was similar to that produced with the positive control ( $2 \mu \mathrm{M} 22^{\prime}, 3^{\prime}$-dideoxythymidine-5'-triphosphate; ddTTP). In addition, $C$. nardus EO had no major biological effects on DNA-POL I, while $10 \mathrm{mM}$ Neomycin as a positive control showed clearly that effect. This enzyme retained up to $91.5 \%$ of its activity compared with the control when the same concentration as in HIV-1 RT assay of $C$. nardus EO $(10 \mathrm{mg} / \mathrm{mL}$, Fig. 1B) was used.

A) HIV-1 RT

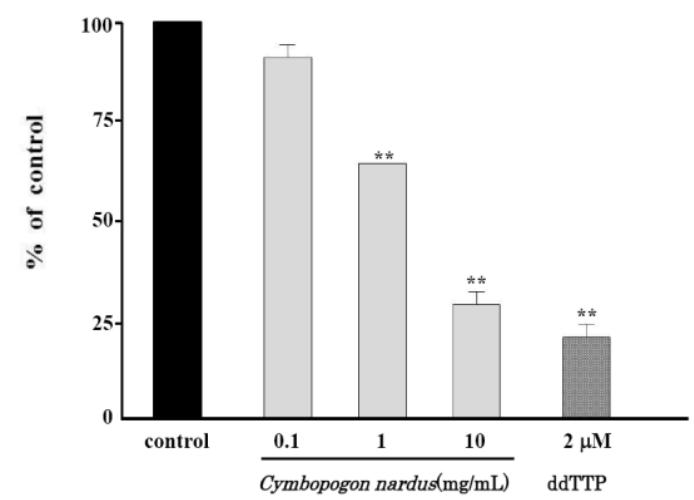

B) DNA-dependent DNA polymerase I

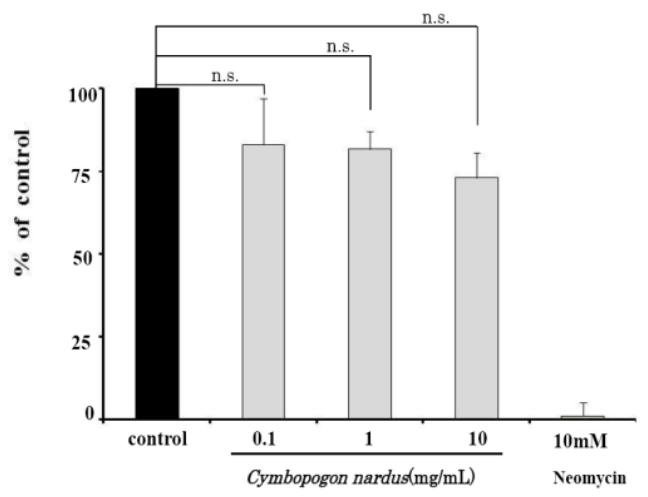

Fig1. Biological effects of Cymbopogon nardus essential oil on HIV-1 RT and DNA-dependent DNA polymerase $I$.

${ }^{*} p<0.005$, compared with control. ${ }^{* *} p<0.001$, compared with control.n.s.: not significant

To investigate the specificity of the inhibitory activity produced by $C$. nardus EO on HIV-1 RT and the inhibitory effect against DNA-POL I, six other representatives EOs were assayed in the same way. 
The results are shown in Table 1. Cymbopogon citratus EO (HIV-1 RT: $\mathrm{IC}_{50}>10 \mathrm{mg} / \mathrm{mL}$; DNA-POL I: $\left.\mathrm{IC}_{50}=9.6 \mathrm{mg} / \mathrm{mL}\right)$, Ocimum gratissimum $\mathrm{EO}\left(\mathrm{HIV}-1 \mathrm{RT}: \mathrm{IC}_{50}>10 \mathrm{mg} / \mathrm{mL}\right.$; DNA-POL I: $\mathrm{IC}_{50}>10$ $\mathrm{mg} / \mathrm{mL}$ ) had no inhibitory effects on the two enzymes. Eucalyptus obliqua leaf EO (HIV-1 RT: $\mathrm{IC}_{50}=$ $4.5 \mathrm{mg} / \mathrm{mL}$, DNA-POL I IC $\mathrm{IC}_{50}>10.0 \mathrm{mg} / \mathrm{mL}$ ), Melaleuca viridiflora leaf EO (HIV-1 RT: $\mathrm{IC}_{50}=1.8$ $\mathrm{mg} / \mathrm{mL}$, DNA-POL I: $\mathrm{IC}_{50}>10.0 \mathrm{mg} / \mathrm{mL}$ ), and Lippia multiflora EO (HIV-1 RT: $\mathrm{IC}_{50}=5.5 \mathrm{mg} / \mathrm{mL}$; DNA-P0L I: $\mathrm{IC}_{50}=9.6 \mathrm{mg} / \mathrm{mL}$ ) had effects on HIV-1 RT and DNA-POL I but they were weak compared with the effects of $C$. nardus on the same enzymes. Thus, none of the other six EOs had the same effects on these enzymes as $C$. nardus EO.

C. nardus EO was subjected to a quantitative GC-MS for analyzing the constituents. The results showed that about 27 peaks were identified (data not shown). Among these, the five commercial available constituents $((R)$-linalool, $(R)$-limonene, geraniol, $(R)$-Citronellal and $(S)$ - $\beta$-citronellol) were selected for further experiments. Then, the activities of these constituents against HIV-1 RT and DNAPOL I were assayed. The results are shown in Table 2 and the chemical structures of the assayed compounds are shown in Fig. 2. (R)-linalool (HIV-1 RT: $\mathrm{IC}_{50}>10 \mathrm{mg} / \mathrm{mL}$; DNA-POL I: $\mathrm{IC}_{50}>10$ $\mathrm{mg} / \mathrm{mL}$ ), $(R)$-limonene (HIV-1 RT: $\mathrm{IC}_{50}>10 \mathrm{mg} / \mathrm{mL}$; DNA-POL I: $\mathrm{IC}_{50}>10 \mathrm{mg} / \mathrm{mL}$ ), geraniol (HIV1 RT: $\mathrm{IC}_{50}=6.5 \mathrm{mg} / \mathrm{mL}$; DNA-POL I: $\left.\mathrm{IC}_{50}=5.6 \mathrm{mg} / \mathrm{mL}\right)$ and $(R)$-citronellal (HIV-1 RT: $\mathrm{IC}_{50}>10$ $\mathrm{mg} / \mathrm{mL}$; DNA-POL I: $\mathrm{IC}_{50}=3.6 \mathrm{mg} / \mathrm{mL}$ ) had very weak effects against HIV-1 RT and DNA - POL I. As shown in Fig. 3A, $(S)$ - $\beta$-citronellol had a dose-dependent inhibitory effect on HIV-1 RT at concentrations ranged from 0.1 to $10.0 \mathrm{mg} / \mathrm{mL}$ (Fig. 3A). With $10 \mathrm{mg} / \mathrm{mL}(S)-\beta$-citronellol, the HIV-1 RT activity was significantly inhibited by up to $63.1 \%$ compared with the control $(p<0.001)$. The positive control treated with $2 \mu \mathrm{M}$ ddTTP inhibited HIV-1 RT in almost the similar way as 10.0 $\mathrm{mg} / \mathrm{mL}(S)-\beta$-citronellol. The data were obtained from three independent experiments. These results demonstrate that $(S)$ - $\beta$-citronellol specifically decreases the activity of HIV-1 RT in a significant manner.<smiles>C=C[C@](C)(O)CCC=C(C)C</smiles><smiles>C=C(C)[C@H]1CC=C(C)CC1</smiles>

1

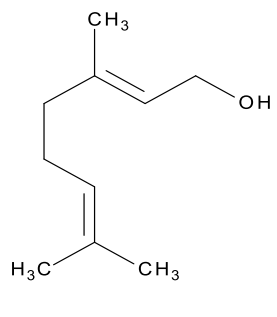

3

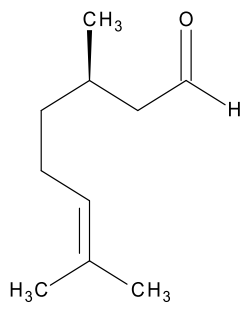

4

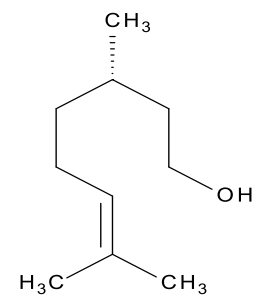

5

Fig2. Chemical structures of someconstituents identified in Cymbopogon nardus essential oil. 1.(R)-Linalool, 2.(R)-Limonene, 3.Geraniol, 4.(R)-Citronellal, 5.(S)- $\beta$-Citronellol

A) HIV-1 RT

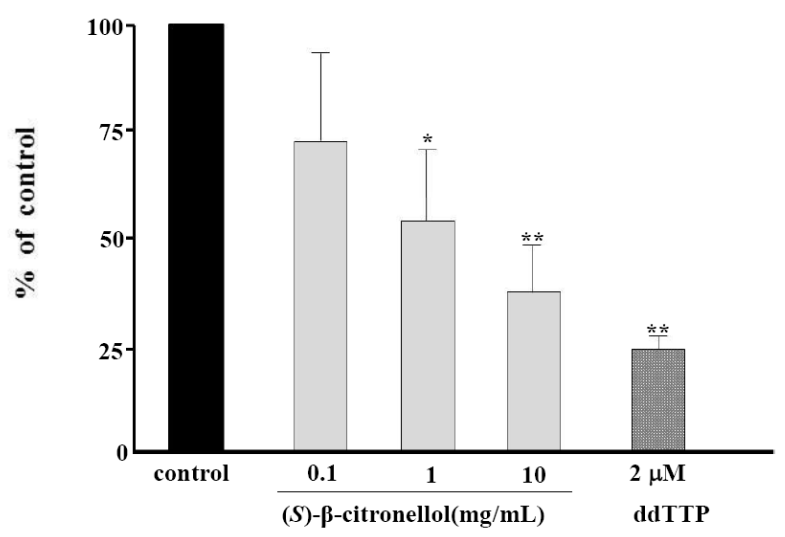

B) DNA-dependent DNA polymerase I

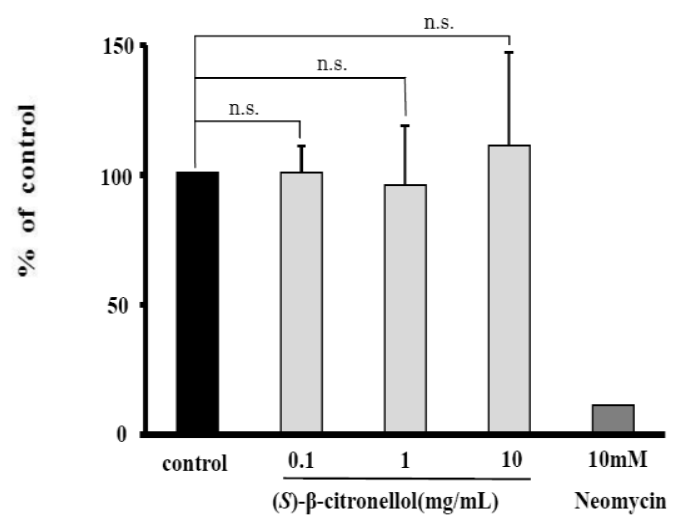

Fig3. Biological effects of (S)- $\beta$-citronellolon HIV-1 RT and DNA-dependent DNApolymerase I. ${ }^{*} p<0.05$, compared with control. ${ }^{* *} p<0.01$, compared with control.n.s.: not significant 
Human Immunodeficiency Virus Type 1 (HIV-1) Reverse Transcriptase Inhibitory Effect of Cymbopogon Nardus Essential Oil

Table1. Biological effects of various essential oils on HIV-1 RT and DNA-POL I

\begin{tabular}{|l|c|c|}
\hline \multirow{2}{*}{\multicolumn{1}{c|}{ Essential oils }} & \multicolumn{2}{c|}{$\mathrm{IC}_{50}(\mathrm{mg} / \mathrm{mL})$} \\
\cline { 2 - 3 } & HIV-1 RT & DNA-POL I \\
\hline Cymbopogon nardus & 1.2 & $>10.0$ \\
\hline Eucalyptusobliqua & 4.5 & $>10.0$ \\
\hline Ocimumgratissimum & $>10.0$ & $>10.0$ \\
\hline Melaleucaviridiflora & 1.8 & $>10.0$ \\
\hline Lippiamultiflora & 5.0 & 9.6 \\
\hline Cymbopogoncitratus & $>10.0$ & 9.6 \\
\hline
\end{tabular}

*DNA-POL I from Escherichia coli lysogenic NM964.

\section{DISCUSSION}

Recent anti-AIDS therapies prioritize the combination of different categories of antiretroviral drugs. Typical combinations usually include two nucleoside RT inhibitors (NRTIs) combined with one protease inhibitor (PI), or two NRTIs combined with one non-nucleoside RT inhibitor (NNRTI). NRTIs are nucleoside analogues with the capacity to competitively inhibit RT activity as chain terminators because of their lack of a 3'-OH group. NNRTIs non-competitively inhibit HIV RT activity by binding to one of it allosteric sites, thereby leading to molecular structure deformation (Balzarini 2004, De Clercq 2004). At present, the most widely used antiretroviral drugs that form the basis of anti-AIDS therapy are RT inhibitors. It is easy to understand that HIV-1 RT became the primary target of anti-AIDS drug research because this enzyme is responsible for generating doublestranded linear DNA from the single-stranded RNA packaged in HIV-1 virions. Previously, researchers focused mainly on chemically synthesized HIV-1 RT inhibitors. Studies of active antiretroviral compounds from natural resources have investigated different parts of many plants (aerial parts and roots, etc.) but no previous reports had considered the HIV-1 RT inhibitory effects of EOs derived from traditional medicinal plant except Bicchi et al. (2009) who reported that EOs from Ridolfia segetum and Oenanthe crocota inhibited HIV-1 RT in a biochemical assay. Bicchi et al. (2009) showed that the active constituents with inhibitory effects in these oils were dillapiol and myristicin. Similarly, the present study of $C$. nardus EO showed that the monoterpenoid $(S)-\beta-$ citronellol $\left(\mathrm{IC}_{50}=3.3 \mathrm{mg} / \mathrm{mL}\right)$ present in this EO also inhibited HIV-1 RT in a dose-dependent manner. This inhibitory effect of $(S)$ - $\beta$-citronellol on HIV-1 RT activity was specific or at least unique among the $C$. nardus EO constituents assayed in the present study (Fig. 3 and Table 2).These results suggest that the anti-HIV-1/AIDS effect of $C$. nardus EO in traditional African medicine may be attributable to the HIV-1 RT inhibitory effect of $(S)$ - $\beta$-citronellol contained in this EO. On the other hand, we reported for the first time that Melaleuca viridiflora leaf EO, Eucalyptus obliqua leaf EO and Lippia multiflora EO had shown inhibitory effects against HIV-1 RT activity but this inhibitory effect is weak as compare with that of $C$. nardus EO. Ramanoelina et al. reported that Melaleuca quinquenervia EO contains (E)-nerolidol, 1,8 cineole, $\alpha$-terpineol and viridiflorol as major constituents. Furthermore, Lippia multiflora EOs contains linalool, germacrene p-cymene, thymol, thymyl acetate and 1,8 cineole as described previously by Juliani et al. (2008). Sefidekon et al. (2007) reported that 1,8 cineol is the main constituent of the essential oil of all eucalyptus species. Although all these works used GC/MS analysis, $(S)$ - $\beta$-citronellol had not been reported in any of these EOs. We then thought worth to conclude that the inhibitory activity of Melaleuca quinquenervia EO, Lippia multiflora EO and Eucalyptus obliqua EO against HIV-1 RT should be attributable to an unknown compound different from $(S)$ - $\beta$-citronellol. Further studies will be needed to identified the active constituents in the above three EOs.

Table2. Biological effects of various chemical constituents of Cymbopogon nardus on HIV-1 RT and DNA-POL

\begin{tabular}{|l|c|c|}
\hline \multirow{2}{*}{ Chemical constituents } & \multicolumn{2}{|c|}{$\mathrm{IC}_{50}(\mathrm{mg} / \mathrm{mL})$} \\
\cline { 2 - 3 } & HIV-1 RT & DNA-POL I $^{*}$ \\
\hline$(R)$-Linalool & $>10.0$ & $>10.0$ \\
\hline$(R)$-Limonene & $>10.0$ & 5.6 \\
\hline Geraniol & 6.5 & 3.6 \\
\hline$(R)$-Citronellal & $>10.0$ & $>10.0$ \\
\hline$(S)$ - $\beta$-Citronellol & 3.3 & \\
\hline
\end{tabular}

*DNA-POL I from Escherichia coli lysogenic NM964.

International Journal of Advanced Research in Botany (IJARB) 


\section{Conclusion}

The present study provides an evidence base for the HIV-1 RT inhibitory effect of $C$. nardus EO in traditional African medicine. ( $S$ )- $\beta$-citronellol may be a potential HIV-1 RT inhibitor and traditional medicines containing $C$. nardus $\mathrm{EO}$ at an appropriate dose may be useful for AIDS therapy.

\section{ACKNOWLEDGMENT}

We thank Mr. Kiyoshi Yono (the president of Medical Support Inc., Tokyo) for a part of financial support in this study.

\section{REFERENCES}

[1] Antonella AM, Alessandro CL, Giovani R, Patrizio P, Andrea A, Andrew NP, Gioacchino A, Vincenzo C, Andrea L. Giuseppe H, Liliana C, Fabrizio S, Gaetano F, Francesco G, Pasquale N. Umberto T, Mauro M. Insights into the reasons for discontinuation of the first highly active antiretroviral therapy (HAART) regimen in a cohort of antiretroviral naïve patients. I.CO.N.A. Study Group. Italian Cohort of Antiretroviral-Naïve Patients. AIDS 2000; 14: 499-507.

[2] Balzarini J. Current status of the non-nucleoside reverse transcriptase inhibitors of human immunodeficiency virus type 1. Current Topics in Medicinal Chemistry 2004; 4: 921-944.

[3] Bär S, Alizon M. Role of ectodomain of the gp41 transmembrane envelope protein of human immunodeficiency virus type 1 in late steps of the membrane fusion process. J Virol 2004; 78 : 811-820.

[4] Barré-Sinoussi F, Chermann JC, Rey F, Nugeyre MT, Chamaret S, Gruest J, Dauguet C, AxlerBlin C, Vézinet-Brun F, Rouzioux C, Rozenbaum W, Montagnier L. Isolation of a Tlymphotropic retrovirus from a patient at risk for acquired immune deficiency syndrome (AIDS). Science 1983; 220: 868-871.

[5] Bauman DJ, Kalyan D, Ho CW, Baweja M, Himmel MD, Clark DAJ, Oren AD, Boyer LP, Hughes HS, Shatkin JA, Arnold E. Crystal engineering of HIV-1 reverse transcriptase for structure-based drug design. Nucleic Acid Res 2008; 36: 5083-5092.

[6] Bicchi C, Rubiolo P, Ballero M, Sanna C, Matteodo M, Esposito F, Zinzula L, Tramontano E. HIV-1-inhibiting activity of the essential oil of Ridolfia segetum and Oenanthe crocata. Planta Med 2009; 75: 1331-1335.

[7] Chen GC, Yu T, Min XH, Zhao L-N, Qing Q, Yuan YH, Su H, Zhan J, Huang K-H, Chen Q-K. Prognosis of 153 patients with decompensated hepatitis B virus-related cirrhosis is improved after 3-year continuous lamivudine treatment. Chin Med J 2013; 126: 1538-1543.

[8] Chou R, Huffman LH, Fu R, Smits AK, Korthuis PT. Screening for HIV: a review of the evidence for the U.S. Preventive Services Task Force. Ann Intern Med 2005; 143: 55-73.

[9] Cohen MS, Hellmann N, Levy AJ, DeCock K, Lange J. The spread, treatment, and prevention of HIV-1: evolution of a global pandemic. J Clin Invest 2008; 118: 1244-1254.

[10] De Clercq E. Non-nucleoside reverse transcriptase inhibitors (NNRTIs): past, present, and future. Chemistry Biodiversity 2004; 1: 44-64.

[11] De Clercq E. Anti-HIV drugs: 25 compounds approved within 25 years after the discovery of HIV. Int J Antimicrob Agents 2009; 33: 307-320.

[12] Dijk VHJ, Sutcliffe GC, Hamangaba F, Bositis C, Waston DC, Moss WJ. Effectiveness of efavirenz-based regimens in young HIV-infected children treated for tuberculosis: a treatment option for resource-limited settings. PLoS One 2013; 8: e55111.

[13] Ducancelle A, Alain S, Petit F, Sanson Le Pors M-J, Mazeron M-C. Development and validation of a non-radioactive DNA polymerase assay for studying cytomegalovirus resistance to foscarnet. J Virol Meth 2007; 141: 212-215.

[14] Gottlieb MS. Pneumocystis pneumonia-Los Angeles. Am J Public Health 2006; 96: 980-981.

[15] Hawkins T. Appearance-related side effects of HIV-1 treatment. AIDS Patient Care STDS 2006; 20: 6-18.

[16] History of HIV and AIDS in Africa. Available at http//www.avert.org/history-aids-africa.htm. Accessed May 07, 2013. 
[17] Juliani HR, Simon JE, Quansah C, Asare E, Akromah R, Acquaye D, Asante-Dartey J, Mensah MLK, Fleischer TC, Dickson R, Annan K, Mensah AY. Chemical diversity of Lippia multiflora essential oils from West Africa. J Essent Oil Res 2008; 20:49-55.

[18] Kudo K, Ishida T, Hikiji W, Hayashida M, Uekusa K, Usumoto Y, Tsuji A, Ikeda N. Construction of calibration-locking databases for rapid and reliable drug screening by gas chromatography mass spectrometry. Forensic Toxicol 2009; 27: 21-31.

[19] Leteane MM, Ngwenya BN, Muzila M, Namushe A, Mwinga J, Musonda R, Moyo S, Mengestu YB, Abegaz BM, Andrae-Marobela K. Old plants newly discovered: Cassia sieberiana D.C. and Cassia abbreviata Oliv. Oliv. root extracts inhibit in vitro HIV-1c replication in peripheral blood mononuclear cells (PBMCs) by different modes of action. J Ethnopharmacol 2012; 141: 48-56.

[20] Park I-W, Han C, Song X, Green AL, Wang T, Liu Y, Cen C, Song X, Yang B, Chen G, He JJ. Inhibition of HIV-1 entry by extracts derived from traditional Chinese medicinal herbal plants. BMC complementary and Alternative Medicine 2009; 9: 29-41.

[21] Ramanoelina PAR, Gaydou EM, Bianchini JP. Caractérisation des huiles essentielles industrielles de niaouli (Melaleuca quinquenervia) de Madagascar -Propositions d'Avant-projet de Normes. available at http:www.madarevues.recherches.gov.mg.

[22] Rosen S, Fox PM, Gill JC. Patient Retention in Antiretroviral Therapy Programs in Sub-Saharan Africa: A Systematic Review, Plos Medicine 2007; 4: e298.

[23] Sarafinos GS, Marchand B, Kalyan D, Himmel D, Parniak AM, Hughes HS, Arnold E. Structure and function of HIV-1 reverse transcriptase: molecular mechanisms of polymerization and inhibition. J Mol Biol 2009; 385: 693-713.

[24] Sayana S, Khanlou H. Maraviroc: a new CCR5 antagonist. Expert Rev Anti Infect Ther 2009; 7: 9-19.

[25] Sefidekon F, Assareh MH, Abravesh Z, Barazandeh MM. Chemical composition of the essential oils of four cultivated Eucalyptus species in Iran as Medicinal Plants (E. microtheca, E. spathulata, E. largiflorens and E. torquata). Iran J Pharm Res 2007; 6: 135-140.

[26] Sepkowitz KA. AIDS-THE FIRST 20 YEARS. N Engl J Med 2001; 344: 1764-1772.

[27] Sharp PM and Hahn BH. Origins of HIV and the AIDS Pandemic. Cold Spring Harb Perspect Med 2011; 1: a006841.

[28] Wei LS, Wee W. Chemical composition and antimicrobial activity of Cymbopogon nardus citronella oil against systemic bacteria of aquatic animals. IJM 2013; 5: 147-152.

[29] World Health Organization, United Nations Programme on HIV/AIDS, United Nations Children's Fund. GLOBAL HIV/AIDS RESPONSE. Epidemic update and health sector progress towards Universal Access. Progress Report 2011. Available at http://www.who.int/hiv/pub/ progress_report2011/en/. Accessed April 08, 2013.

[30] World Health Organization. World AIDS Day 2012: Closing in on global HIV targets. Available at http:www.who.int/mediacentre/news/notes/2012/aids_20121129/en/index.html. April 08, 2013.

[31] Yu F, Lu L, Du L, Zhu X, Debnath KA, Jiang S. Approaches for identification of HIV-1 entry inhibitors targeting gp41 pocket. Viruses 2013; 5: 127-149.

[32] Ziske J, Kunz A, Sewangi J, Lau I, Dugange F, Hauser A, Kirschner W, Harms G, Theuring S. Hematological changes in women and infants exposed to an AZT-containing regimen for prevention of mother-to-child-transmission of HIV in Tanzania. PLoS One 2013; 8: e55633.

\section{AUTHOR's BIOGRAPHY}

Kazuya Mori, Department of Biochemistry, Yokohama University of Pharmacy, Matano-chou 601, Totsuka-ku, Yokohama, Kanagawa, Japan. 